\title{
Acute toxicity and histopathology in ornamental fish amazon bluespotted corydora (Corydoras melanistius) exposed to formalin
}

\author{
RUDÃ F.B. SANTOS ${ }^{2}$, HENRIQUE M. DIAS ${ }^{2}$ and RODRIGO Y. FUJIMOTO ${ }^{1}$ \\ ${ }^{1}$ Empresa Brasileira de Pesquisa Agropecuária, Embrapa Tabuleiros Costeiros, \\ Av. Beira Mar, 3250, 49025-040 Aracaju, SE, Brasil \\ ${ }^{2}$ Universidade Federal do Pará, Campus Universitário de Bragança, Faculdade de Engenharia de Pesca, \\ Laboratório de Ictioparasitologia e Piscicultura, Alameda Leandro Ribeiro, s/n, 68600-000 Bragança, PA, Brasil \\ Manuscript received on June 21, 2011; accepted for publication on September 27, 2011
}

\begin{abstract}
The objective of this work was to evaluate the acute toxicity of formalin and histopathological effects on the Amazon ornamental fish, bluespotted coridora (Corydoras melanistius). A randomized design was used, with ten concentrations of formalin $(40 \%)\left(0,3,6,12,25,50,100,150,200\right.$ and $\left.250 \mathrm{mg} . \mathrm{L}^{-1}\right)$ with four replicates and five fish per container (3L) in static system for 96 hours. The moribund fish were killed and fixed in $10 \%$ formalin to proceed the histopathological analysis of gill, liver and kidney. At the end of this experiment the following mortality rates (\%) were obtained in increasing order of exposure: $0,0,0$, $0,0,65,85,100,100$ and $100 \%$. The lethal concentration $50 \%\left(\mathrm{LC}_{50-96 \mathrm{~h}(\mathrm{I})}\right)$ estimated was $50.76 \mathrm{mg} . \mathrm{L}^{-1}$ with regression of $\mathrm{y}=0.51 \mathrm{x}$, and $\mathrm{r} 2=0.80$. Further, in higher concentrations morphological changes as gill hyperplasia, with filling of interlamellar spaces, disorganization of liver arrangement, and necrosis in kidney were observed. In this study, the formalin can be considered slightly toxic to bluespotted corydora, and cause morphological changes when exposed to high concentrations. The use of formalin to treat of ornamental fish in the inner river of capture with wrong concentration can provoke negative environmental and biological effects.
\end{abstract}

Key words: Lethal concentration, corydora, formaldehyde, toxicity, histology, Amazon.

\section{INTRODUCTION}

The species of genus Corydoras have benthic habits and are considered ornamental fish with appreciation in the international market due to its rusticity and color patterns. In the Amazon region, they are captured in rivers and streams and exported to countries like Japan and United States.

In Northeastern Pará state, the Corydoras is captured in the Middle Guamá river, representing

Correspondence to: Rudã Fernandes Brandão Santos

E-mail: ruda_fernandes@hotmail.com
$62 \%$ of the total captured in that region, which corresponds to approximately 500,000 individuals (M.F. Torres et al., unpublished data).

However, during handling and after capture are reported mortality rates between $3 \%$ and $15 \%$ of the total catch (M.F. Torres et al., unpublished data). M.F. Torres et al., unpublished data reported the use of different chemotherapeutic agents such as malachite green, methylene blue and formaldehyde as preventive management strategies for ornamental fish before exportation. However, the 
main problem in the marketing chain of these fishes was the wrong administration of chemotherapeutic concentration, thereby causing financial, biological and environmental loss for the effluents that could reach water bodies (Baca apud M.F. Torres et al., unpublished data).

The risk of environmental contamination by chemotherapy tends to increase in this region, as many basins of the Amazon already reported cases where the fishermen used chemical products in the inner river where fishes were captured, without care and technical guidance (M.F. Torres et al., unpublished data; Souza and Mendonça 2009).

Thus, studies to improve management and reduce mortality are important for the sustainability of the chain. And faced with this, to protect and monitor the environment, the aquatic toxicity bioassays are conducted for various purposes such as environmental regulations, approval and registration of commercial chemical products, and evaluation of drugs for disease treatment of aquatic organisms. (Lombardi 2004). Formaldehyde is used in aquaculture to control bacterial diseases, fungal and parasitic diseases, demonstrating efficacy in short term baths (Fajer-Ávila et al. 2003). However, the formaldehyde is a mutagen and carcinogen even at low concentrations and presented toxicity in a variety of organisms. In aquatic organisms, deleterious effects were observed on the concentration of $1 \mathrm{mg} . \mathrm{L}^{-1}$ for fish and $5 \mathrm{mg} . \mathrm{L}^{-1}$ for microcrustaceans and algae. (C.R.T. Farah et al., unpublished data).

The effects of these products in fish can be manifested at various levels of biological organization, including physiological dysfunction, structural changes in organs and tissues and behavioral changes that lead to impaired growth and reproduction. Among the morphological changes observed in organs of fishes exposed to xenobiotics are: gill hyperplasia (Henares et al. 2008), disarrangement and vacuolization of hepatocytes and focal necrosis in liver (Rodrigues and Fanta 1998, Santos et al. 2004). These biological responses to stress caused by xenobiotics can be used to identify early signs of damage to fish (Winkaler et al. 2001).

The objective of this work was to assess the acute toxicity of formalin to bluespotted corydora (Corydoras melanistius) determining the CL50 and evaluated its effects on gills, liver and kidney through the identification of histopathological changes.

\section{MATERIALS AND METHODS}

The tests of acute toxicity of formalin for bluespotted corydora were performed at the Laboratory of Fish Culture and Ictioparasitology Campus of Bragança-PA, the fishes were collected in the Guamá river (Northeastern Pará) with aid of local fishermen, then transported to the laboratory and acclimated in water tanks of $300 \mathrm{~L}$ for a period of seven days in order to recover from the capture and transportation stress. After this period, the fishes were used for the assays. The weight of fish used was $3.2 \mathrm{~g} \pm 0.46 \mathrm{~g}$.

The experiment was conducted in 5 L containers with a volume of $3 \mathrm{~L}$, where in each container were placed $2 \mathrm{~L}$ of water followed by the fish distribution and then adding the remaining liter with the concentration of product test. All containers were supplied with artificial aeration and constant stocking density of five fish per container. They remained in a static system for 96 hours. A randomized design was used with ten concentrations of formalin (0.3, $6,12,25,50,100,150,200$ and $\left.250 \mathrm{mg} . \mathrm{L}^{-1}\right)$ and four replicates each.

The behavior and mortality rates were monitored every hour during the first 12 hours and the every 6 hours until the end of the experiment (96 hours).

The parameters of water such as dissolved oxygen, temperature, $\mathrm{pH}$ and conductivity were measured daily, and total ammonia was monitored before and after the experiment with the aid of a photocolorimeter $\left(\mathrm{HANNA}^{\circledR}\right)$.

Data were analyzed by the Trimmed Spearman Karber (Hamilton et al. 1977) to determine the 
LC50. Following that data were plotted on linear regression from the application Bioestat 5.0.

To perform the histopathological analysis at all times of monitoring, recently dead fish or moribund fishes were collected and then accounted as dead. These fishes were fixed in formalin 10\%. After 48 hours the fishes were dissected and the fragments of gills, liver and kidney were removed and then preserved in alcohol $70^{\circ}$. These fragments were included in paraplast to prepare histopathological sections of $5 \mu \mathrm{m}$ thick, and stained with hematoxylin/ eosin according Behmer et al. (1976).

\section{RESULTS AND DISCUSSION}

The water quality monitored had a $\mathrm{pH}$ of $5.2 \pm$ 0.26 , dissolved oxygen showed values of $6.94 \pm$ $0.37 \mathrm{mg} . \mathrm{L}^{-1}$, the temperature presented values of 27. $1 \pm 0.11^{\circ} \mathrm{C}$, the conductivity $318.42 \pm 16.93$ $\mathrm{mS} . \mathrm{cm}^{-1}$ and ammonia of $0.011 \mathrm{mg} . \mathrm{L}^{-1}$, and none of these variables were restricted to the maintenance of fishes in this condition, remaining within the range recommended by ABNT (2006).

After 96 hours of exposure to formaldehyde the following rates of mortality were found: $100 \%$ mortality at concentrations 250, 200 and
$150 \mathrm{mg} . \mathrm{L}^{-1}, 85 \%$ in the concentration $100.0 \mathrm{mg} . \mathrm{L}^{-1}$ and $65 \%$ at a concentration of $50 \mathrm{mg} . \mathrm{L}^{-1}$ and no mortality in the other concentrations. Thus estimated the LC $50-96 \mathrm{~h}$ (I) of $50.76 \mathrm{mg} . \mathrm{L}^{-1}$ with lower limit of $44.37 \mathrm{mg} . \mathrm{L}^{-1}$ and the upper limit of $60.39 \mathrm{mg} \cdot \mathrm{L}^{-1}$ with the following regression $\mathrm{y}=0.51$ $\mathrm{x}$ with $\mathrm{r}^{2}=0.80$ (Figure 1).

Fishes exposed to formalin concentrations showed two patterns of behavior during the first 24 hours. Fishes exposed to higher concentrations presented agitation, followed by erratic swimming and positioning on the water surface immediately after the addition of the substance. While the fishes submitted to the lower concentrations remained standing, making small movements and resting at bottom of containers.

The behavior observed in corydoras as erratic swimming and standing on the surface, observed in the highest concentrations of formaldehyde corroborates as described that fishes subjected to acute poisoning with xenobiotics presented behavioral changes such as erratic swimming, also retarded growth, biochemical, histopathological and hematological disorders (C.F. Salles-Dias, unpublished data).

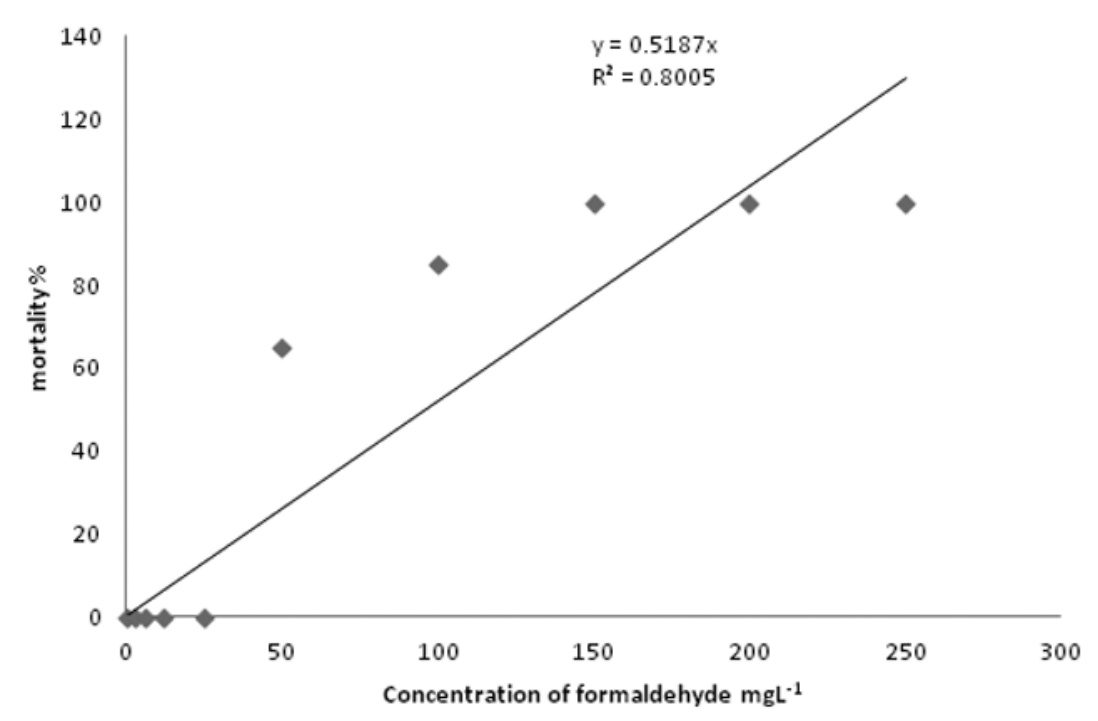

Figure 1 - Relação concentração-mortalidade da corredora bicuda (Coridora melanistius cf.) para o formol durante o teste de toxicidade aguda. 
Compared with the literature, the formalin was more toxic to bluespotted corydora $\mathrm{LC}_{50}$ (I) 50.75 $\mathrm{mg} . \mathrm{L}^{-1}$ than to trairão (H. lacerdae) larvae with $\mathrm{LC}_{50}$ (I) of $2.02 \mathrm{Ml}^{-1} \mathrm{~L}^{-1}$ (Cruz et al. 2005). According Abessa (2006) biological factors such physiological conditions, nutritional status and stage in life cycle may interfere with chemical absorption rate, then fish larvae tend to be more sensitive xenobiotic action then juvenile or adult animals. However, each species responds differently to the action of a substance, therefore the importance of conducting toxicity tests with different organisms.

Fajer-Ávila et al. (2003) evaluated the efficacy of formalin to control ectoparasites of fish "bullseye" Sphoeroides annulatus, determining CL ${ }_{50-96 \mathrm{~h} \mathrm{(I)}}$ of $1095 \mathrm{mg} \cdot \mathrm{L}^{-1}$ (30 $\left.\mathrm{min}\right)$ and 972 $\mathrm{mg} . \mathrm{L}^{-1}(60 \mathrm{~min})$ and $79 \mathrm{mg} . \mathrm{L}^{-1}(72 \mathrm{~h})$, this last level showing similar toxicity to bluespotted corydora in 96 hours. MacNiven and Little (2001) determined the LC ${ }_{50-96 \mathrm{~h}(\mathrm{I})}$ of $429.68 \mathrm{mg} . \mathrm{L}^{-1}$ of formaldehyde for tilapia (Oreochromis niloticus), showing that formaldehyde was more toxic to corydora than tilapia.

According Tisler and Koncan (1997) the formaldehyde presented more toxic activity for temperate fish in concentration range of 15 to 30 $\mathrm{mg} . \mathrm{L}^{-1}$. For rainbow trout (Oncorhynchus mykiss) the LC50 $48 \mathrm{~h}$ of formalin concentration of $6.1 \mathrm{mg} . \mathrm{L}^{-1}$ was determined. Since the bluespotted corydora presented higher value of LC50 with $50.76 \mathrm{mg} . \mathrm{L}^{-1}$, it confirmed the previously stated by the authors.

According Zucker (1985) thus adapting to the conditions of this study, the formaldehyde can be considered as slightly toxic to the bluespotted corydora.

However, when the objective is the sustainability of ornamental fish marketing chain, the classification of formaldehyde in low toxicity does not guarantee that it can be used without compromising animal welfare, therefore it cannot measure the deleterious effects that the substance causes to the body subjected to experimental testing.
Therefore, histopathological changes in fish tissue can be used as a tool to detect the direct toxic effects of chemicals in target organs (Schwaiger et al. 1997), because they reflect the damage caused by duration and intensity of exposure to toxic element and the tissue adaptive capacity (Ferreira et al.. 2004). Moreover, the histology can validate the use of a substance based on animal welfare, which is part of the policy of some companies and organizations like the Ornamental Fish International (OFI), which has a code of ethics where the priority of the companies that compose it, is the animal welfare at all stages of the ornamental fish marketing chain.

In the present work the structures of the organs analyzed by histopathological analysis in the control treatment, 3, 6 and $12 \mathrm{mg} . \mathrm{L}^{-1}$, are similar to others fishes described in literature as channel catfish (Ictalurus punctatus) (Grizzle and Rogers 1985) and pacu (Piaractus mesopotamicus) (Fujimoto et al. 2008).

However, in gill, at higher levels (above 50 mg.L. $\mathrm{L}^{-1}$ ) cell hyperplasia occurred, reaching levels of filling interlamellar spaces (Figure $2 a$ and $2 b$ ). According Reardon and Harrell (1990), the toxicity of formaldehyde is the cause of pathological damage in the gills, causing a gill dysfunction, osmoregulatory and respiratory imbalance and mortality. This is due to the fact that the gill epithelium is the primary contact surface, by having a large surface area, with the external environment, became a target of the pollutants present in the water (Wong and Wong 2000). This epithelial hyperplasia with filling of the interlamellar spaces is described in several fish in response to a variety of agents, from heavy metals as cadmium (Garcia-Santos 2007) to herbicides such as atrazine (Jayachandran and Pugazhendy 2009) like a primary strategy for fish protection. In Corydora paleatus (Fanta et al. 2003) the gills after 24 hours of exposure to organophosphates presented a detachment of gill epithelium, but this effect was not observed in the bluespotted corydora. 
In liver, at lower concentrations, as well as gills, no changes were observed during the experiment, but in higher concentrations (above $50 \mathrm{mg} \cdot \mathrm{L}^{-1}$ ), the sinusoids capillaries were congested (Figure $3 \mathrm{a}$ ) and structurally, the hepatocytes presented hypertrophic with changes in cytoplasmatic granulation and no more displayed in a cordon disposition. No hepatocytes vacuolization was observed. Fujimoto et al. (2008) studying pacu fed organic chromium also observed hepatocytes disarray and congestion of the capillaries. In Coridora sp. exposed to organophosphates, observed after 96 hours, the hepatocytes presented eosinophilia and brown granules indicating accumulation of bile (Fanta et al. 2003). In response to this xenobiotic, pyknotic nuclei were also observed, but not in the liver of bluespotted corydora exposed to formalin. Cruz et al. (2005) also found hepatocytes disarray for larvae of Hoplias lacerdae submitted to the concentration of formaldehyde $\left(7 \mathrm{ml} . \mathrm{L}^{-1}\right)$ after 96 hours of exposure. According Rodrigues and Fanta (1998) the disarray and vacuolization of hepatocytes were observed in liver of Brachidanio rerio exposed to organophosphate.

In kidneys, in the high concentrations of formalin (above $50 \mathrm{mg} . \mathrm{L}^{-1}$ ) after 96 hours exposure there was congestion of the capillaries (50 mg. $\mathrm{L}^{-1}$ ) (Figure 3b), and focal necrosis (100 mg. $\mathrm{L}^{-1}$ ) (Figure 3c) and in addition to that increase in Bowman's space and necrosis of renal tubules (Figure 3c). Albinati et al. (2009) also observed in piauçu (Leporinus macrocephalus) exposed to $1.58 \mathrm{mg} . \mathrm{L}^{-1}$ of Roundup ${ }^{\circledR}$ for 14 days,
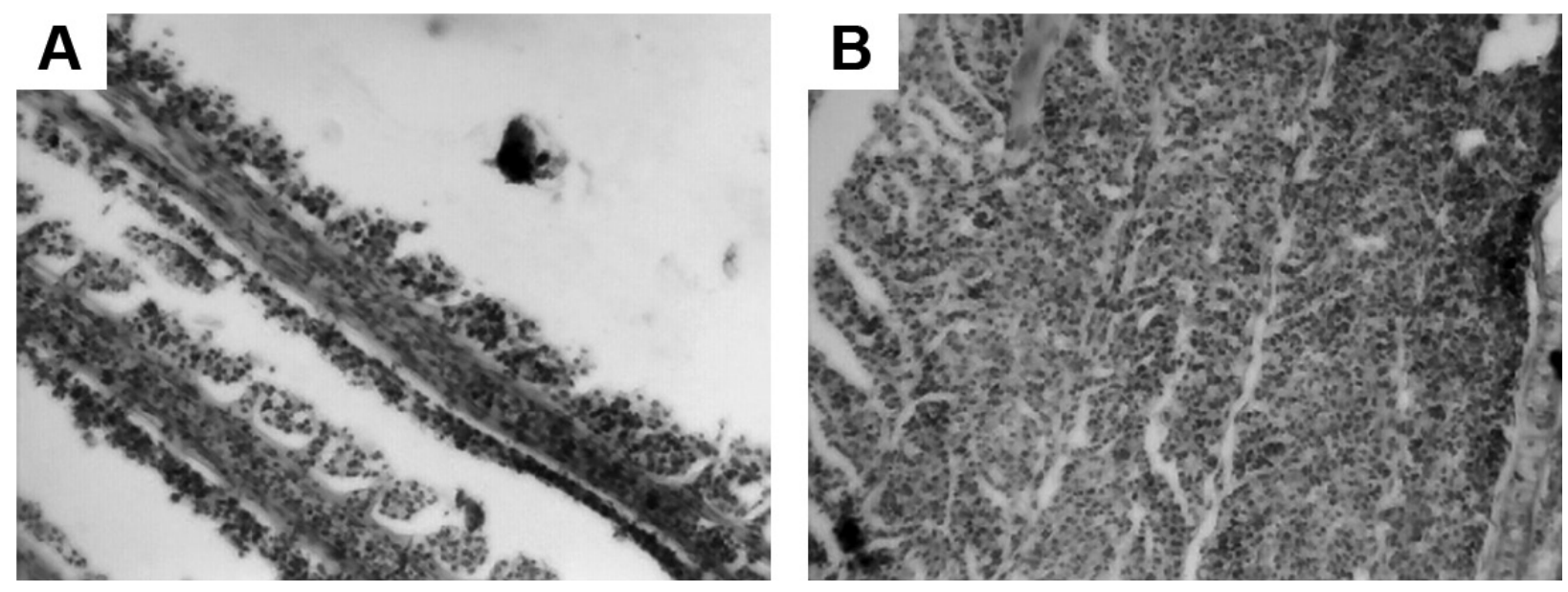

Figure 2 - a. Gill lamellae of Coridora exposed at concentration of $50 \mathrm{mg} . \mathrm{L}^{-1}$ formaldehyde showing hyperplasia. HE 200x. b. Gill lamellae of Coridora in concentration of $100 \mathrm{mg} . \mathrm{L}^{-1}$ formaldehyde showing epithelial hyperplasia with filling of interlamellar spaces. HE 200x.
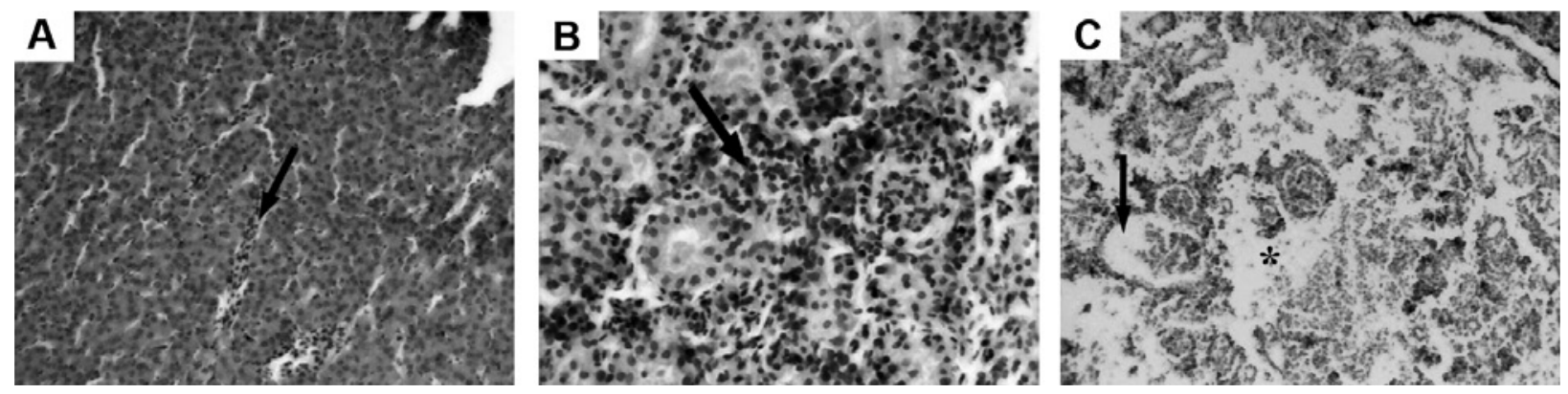

Figure 3 - a. Liver of Coridora in concentration of $50 \mathrm{mg} . \mathrm{L}^{-1}$ of formaldehyde present congestion (arrow). HE 400x. b. Kidney of coridora exposed at concentration of $50 \mathrm{mg} . \mathrm{L}^{-1}$ of formaldehyde present congestion (arrows). HE 400x. c. Kidney of coridora in concentration of $100 \mathrm{mg} . \mathrm{L}^{-1}$ formaldehyde showing necrosis $(*)$ and increased Bowman's space (arrow). HE 100x. 
congestion associated renal tubular vacuolization and increase in Bowman's space, similar to the present work.

In the Amazonian region where were reported concentration of incorrect administration of prophylactic chemotherapy baths as a routine procedure for native fish by exporters (Baca apud Torres, M. F. et al. unpublished data), studies on the determination of the chemotherapy effectiveness and of its deleterious effects by assays in these species are essential. For the present study, the prophylactic treatments in Corydora melanistius should be performed at lower concentrations of formaldehyde.

\section{ACKNOWLEDGMENTS}

To the Conselho Nacional de Desenvolvimento Científico e Tecnológico (National Counsel of Technological and Scientific Development (CNPq) for the scholarships to students and financial support to the research.

\section{RESUMO}

O objetivo do trabalho foi determinar a toxicidade aguda de formalina e os efeitos histopatológicos para o peixe ornamental amazônico corredora bicuda (Corydora melanistius). Foi utilizado um delineamento inteiramente casualizado; com dez concentrações de formalina $40 \%(0,3,6,12,25,50,100,150,200 \mathrm{e}$ $\left.250 \mathrm{mg} . \mathrm{L}^{-1}\right)$, com quatro repetições e cinco peixes por recipiente de água $(3 \mathrm{~L})$ em sistema estático durante 96 horas. Os peixes moribundos foram mortos e fixados em formol $10 \%$ procedendo à análise histopatológica das brânquias e do fígado. Ao final desse experimento, obtiveram-se as seguintes taxas de mortalidades em ordem crescente de exposição (\%): $0,0,0,0,0,65,85$, 100, 100 e 100. A concentração letal 50\% (CL inicial (I) $50-96 \mathrm{~h}$ ) foi estimada em $50,76 \mathrm{mg} / \mathrm{L}$ com a seguinte equação de regressão $\mathrm{y}=0,51 \mathrm{x}$ com $\mathrm{r} 2=0,80$. Pode observar nas concentrações mais elevadas, alterações como hiperplasia branquial e fusão lamelar, enquanto que no fígado foi observado desorganização do arranjo cordonal, assim como necrose no rim. Com isso no presente estudo, a formalina pode ser considerada pouco tóxica para a corredora bicuda, mas causa alterações morfológicas acentuadas quando expostas a concentrações elevadas. Dessa forma o uso de formalina no próprio rio de coleta dos peixes com a utilização de dosagens erradas pode causar impactos ambientais e biológicos negativos.

Palavras-chave: concentração letal, corydora, formaldeído, toxicidade, histologia, Amazônia.

\section{REFERENCES}

ABESSA DMS. 2006. Ecotoxicologia marinha. In: Sanidade de organismos aquáticos no Brasil, Souza-Silva AT (Ed), Abrapoa, p. 19-41.

ALbinati ACL, MOREIRA ELT, ALBINATI RCB, CARVALHO JV, DE LiRA AD, SANTOS GB AND VIDAL LVO. 2009. Biomarcadores histológicos - toxicidade crônica pelo Roundup em piauçu (Leporinus macrocephalus). Arq Bras Med Vet Zootec 61(3).

ABNT - AsSOCIAÇÃo BRASILEIRADE NORMAS TECNICAS. 2006. NBR 15350. Ecotoxicologia aquática - Toxicidade crônica de curta duração - Método de ensaio com ouriço do mar (Echinodermata: Echinoidea).

Behmer AO, Tolosa EMC and Feritas-Neto AG. 1976. Manual de técnicas para histologia normal e patológica. Edart/Edusp, São Paulo, 239 p.

Cruz C, FuJimoto RY, LuZ RK, PORTElla MC AND MARTins ML. 2005. Toxicidade aguda e histopatologia do fígado de larvas de trairão (Hoplias lacerdae) expostas à solução aquosa de formaldeído a 10\%. Pesticidas: ecotoxicol. e meio ambiente 15: 21-28.

FAJER-Ávila EJ, PARRA IA, ZARATE GA, ARCE RC, RAMÍREZ JZAND LOZANO MB. 2003. Toxicity of formalin to bullseye puffer fish (Sphoeroides annulatus - Jenyns, 1843) and its effectiveness to control ectoparasitas. Aquaculture 223: 41-50.

FAnTA E, Rios FS, Romão S. Vianna AC, CASAgRande C AND REIBERGER S. 2003. Histopathology of the fish Corydoras paleatus contaminated with sublethal levels of organophosphorus in water and food. Ecotoxicol Environ Saf 54: 119-130.

Ferreira M, ANTUNes P, GIL O, VALE C AND REIS-HENRIQUES MA. 2004. Organochlorine contaminants in flonder (Platichthys flesus) and mullet (Mugil cephatus) from Douro estuary, and their use as sentinel speiceis for environmental monitoring. Aquat Toxicol 69: 347-357.

Fujimoto RY, CRUZ C AND Moraes FR. 2008. Análise de efluente e histologia da pele, fígado e rim de pacus (Piaractus mesopotamicus) suplementados com cromo trivalente. B Inst Pesc 34: 117-124. 
Garcia-SANTOS S, MONTEIRO SM, CARROLA J AND FONTAINHAS FA. 2007. Alterações histológicas em brânquias de tilápia nilótica Oreochromis niloticus causadas pelo cádmio. Arq Bras Med Vet Zootec 59: 376-381.

GRIZZLE JM AND ROGERS WA. 1985. Anatomy and Histology of the Channel Catfish, Auburn, Alabama, ed., Auburn University, 94 p.

HAMILTON MA, Russo RC AND THURSTON V. 1977.Trimmed Spearman-Karber method for estimating medial lethal concentrations in toxicity bioassays. Environ Scien Techonol 7: 714-719.

Henares MNP, Cruz C, Gomes GR, Pitelli RA AND MACHADO MRF. 2008. Toxicidade Aguda e Histopatologia do Herbicida Reward ${ }^{\circledR}$ na Brânquia e no Fígado do Pacu (Piaractus mesopotamicus). Maringá 30(1): 77-82.

JAYACHANDRAN K AND PUGAZHENDY K. 2009. Histopathological Changes in the Gill of Labeo rohita (Hamilton) Fingerlings Exposed to Atrazine. Am Eurasian J Sci Res 4: 219-221.

LOMBARDI JV. 2004. Fundamentos de toxicologia Aquática In: Sanidade de organismos Aquáticos. Ranzani Paiva MJT, Takemoto RM, Lizama MAP (Eds), Varela. São Paulo, p. 263-272.

MACNIVEN AM AND LitTle DC. 2001. Development and evaluation of a stress challenge testing methodology for assessment of Nile tilapia (Oreochromis niloticus, Linn.) fry quality. Aquacul Res 32: 671-679.

REARDON IS AND HARRELL RM. 1990. Acute toxicity of formalin and copper sulfate to shipped bass fingerlings held in varying salinities. Aquaculture 87: 255-270.

RODRIGUES EL AND FANTA E. 1998. Liver histopathology of the fish brachydanio rerio Hamilton-buchman afer acute exposure to sublethal levels of the organophosphate dimethoate 500. Rev Bras Zool 15(2): 441-450.
SANTOS AA, RANZANI-PAIVA MJT, FELIZARdo NN AND RODRIGUES EL. 2004. Analise histopatólogica de figado de tilapia-do-nilo, Oreochromis niloticus, criada em tanque-rede na represa de Guarapiranga, São Paulo, SP, Brasil. B Inst Pesca, São Paulo 30(2): 141-145.

Schwaiger J, Wanke U, Adam S, PaWert M, Honnen W AND TRIEBSKORN R. 1997. The use of histopathological indicators to evaluate ontaminant-related stress in fish. J Aquat Ecosyst Stress and Recov 6: 75-86.

SouZA RL AND MENDONÇA MR. 2009. Caracterização da pesca e dos pescadores de peixes Ornamentais da região de Tefé/AM. UAKARI 5(2): 7-17.

TISLER T AND KONCAN JZ. 1997. Comparative assessment of phenol, formaldehyde and industrial wastewater to aquatic organisms. Earth and Environmental Science 97: 315-322.

Winkaler EU, Silva AG, GaLindo HC AND MarTineZ CBR. 2001. Biomarcadores histológicos e fisiológicos para o monitoramento da saúde de peixes de ribeirões de Londrina, Estado do Paraná. Acta Sci Maringá, 23: 507-514.

Wong CK AND WONG MH. 2000. Morphological and biochemical changes in the gills of Tilapia (Oreochromis mossambicus) to ambient cadmium exposure. Aquatic Toxicol 48: 517-527.

ZUCKER E. 1985. Hazard evaluation division - Standard evaluation procedure - Acute toxicity test for freshwater fish. USEPA publication 540/9-85-006, Washington, 17 p. Disponível em:<www.epa.gov> [Acessado em 18 de março de 2007]. 